\title{
Determination of Genetic Diversity in European Cranberrybush(Viburnum opulus L.) Genotypes Based on Morphological, Phytochemical and ISSR Markers
}

mehmet yaman ( $\nabla$ mhmt.-07@hotmail.com )

Erciyes Universitesi

\section{Research Article}

Keywords: European Cranberrybush, genetic diversity, morphology, ISSR, phytochemical

Posted Date: November 9th, 2021

DOI: https://doi.org/10.21203/rs.3.rs-1059583/v1

License: (9) This work is licensed under a Creative Commons Attribution 4.0 International License.

Read Full License

Version of Record: A version of this preprint was published at Genetic Resources and Crop Evolution on February 3rd, 2022. See the published version at https://doi.org/10.1007/s10722-022-01351-4. 


\section{Abstract}

Turkey's plant diversity varies considerably. Many of these plants are native and commercially grown. European Cranberrybush, which is among the fruit species grown economically in the country, is also of interest in terms of health. In this study, it was aimed to determine genetic diversity with morphological, molecular, and phytochemical markers in 24 different genotypes from Kayseri province, which has an important place in the production of European Cranberrybush in Turkey. The results show that wide variations were detected between genotypes in the morphological parameters. While the genotype G13 was the prominent genotype compared to other genotypes in leaf length $(130.69 \mathrm{~mm})$, leaf width $(135.76$ $\mathrm{mm}$ ) and fruit length $(10.01 \mathrm{~mm})$, the range in fruit weights of genotypes varied between $0.16 \mathrm{~g}$ and 0.80 g. In ISSR marker analysis, a total of 73 scoreable bands were obtained from 11 different primers, and 44 of these bands were polymorphic bands. The average polymorphism rate in the study was $60.27 \%$, and the similarity index of the genotypes varied between 0.77 and 0.95 . Total flavonoid, total phenolic and total anthocyanin contents ranged from $106.28 \mathrm{mg} \mathrm{CAE} / 100 \mathrm{~g}$ to $318.87 \mathrm{mg}$ CAE/100 g, $451.23 \mathrm{mg}$ GAE/100 g to $679.57 \mathrm{mg} \mathrm{GAE} / 100 \mathrm{~g}, 21.36 \mathrm{mg}$ cyn-3-gluc /100 g to $16.48 \mathrm{mg}$ cyn-3-gluc /100 g, respectively. It is thought that the results of the study may be useful to plant breeders in terms of its development and preservation, as well as giving an opinion to the researchers in new studies to be carried out in the European Cranberry.

\section{Introduction}

Turkey is a very important country in the world in terms of plant diversity. (Gümüş and Avcl., 2020; Ozturk et al., 2020). This genetic diversity has spread throughout the country, and most plant species are grown naturally and economically in Turkey. European Cranberyybush (Viburnum opulus L.) is one of the fruits that has increased in production in recent years, it is from the Caprifoliaceae family (Al et al., 2017), and Europe, Northwest Africa, Turkestan, and Canada are accepted as the homeland for European Cranberrybush(ECB) (Richard and Pierre 1992; Ozrenk et al., 2020).

ECB is grown in Tokat, Artvin, Samsun, Trabzon, Sivas, Erzurum, Bursa, Izmit, Sakarya, Istanbul, Izmir, Kirsehir, Ankara, Kahramanmaras provinces in Turkey, and it grows more especially in Kayseri than other provinces (Yıldız and Ekici, 2009). In Turkey, ECB is used as an ornamental plant in home gardens, fresh consumption (Kajszczak et al., 2020), fruits as beverage, dried and used as marmalade (Kalyoncu et al., 2013). In addition to these areas of use, it is a plant that is valued for its medicinal properties. ECB's juice is used for different purposes such as colds, kidney disease and especially diabetes. (Eryilmaz et al., 2013).

Different studies are carried out to determine genetic diversity in plants, both for breeding purposes and for the protection of the species. (Hosseinpour et al., 2020). These studies were generally made on morphological and phytochemical characters. However, it should be considered that morphological and phytochemical properties of plants can be affected by environmental conditions. (Schneider et al., 2017). Therefore, it is necessary to focus on molecular marker systems that will provide reliable results in 
studies to be carried out to determine genetic diversity and where environmental conditions are not affected. (Yu, 2020). In addition, considering that some features such as yield, quality, resistance to diseases and pests in plants are controlled by multiple genes, there is a need for multidisciplinary studies in which morphological, biochemical, and molecular marker analyzes are combined. These studies, which were also carried out in the ECB species, were generally morphological (Ozkan et al., 2020), molecular (Krupa-Małkiewicz et al., 2014) and phytochemical (Polka et al., 2019), and multidisciplinary studies are almost nonexistent in the literature.

In this study, it was aimed to determine the genetic diversity of 24 different ECB genotypes with some morphological, phytochemical, and molecular markers in the Kayseri province, where the ECB population is dense in Turkey.

\section{Material And Method}

\section{Material}

24 different genotypes of ECB were used as material in this study. Genotypes were determined by selection from "Talas, Bünyan, Develi, Sarıoglan, Yahyalı" and "Melikgazi" districts of Kayseri province, which has an important place in ECB production in Turkey and is in the center of Central Anatolia. (Table 1). In these districts, ECB genotypes are generally grown in home gardens for landscaping and commercially (Figure 1). The leaves of the genotypes were taken in the middle of the summer season (July) and frozen in liquid nitrogen, brought to the laboratory and stored at $-80 \mathrm{C}$ until the analyzes were performed. 
Table 1

Some information about the regions where ECB genotypes were taken.

\begin{tabular}{|c|c|c|c|}
\hline Genotype & Coordinate & Altitude (m) & District \\
\hline G1 & $39^{\circ} 11^{\prime} 29^{\prime \prime} \mathrm{N} 35^{\circ} 56^{\prime} 10^{\prime \prime} \mathrm{E}$ & 1147 & Sarıoğlan \\
\hline G2 & $39^{\circ} 11^{\prime} 27^{\prime \prime} \mathrm{N} 35^{\circ} 56^{\prime} 10^{\prime \prime} \mathrm{E}$ & 1145 & Sarıoğlan \\
\hline G3 & $39^{\circ} 11^{\prime} 15^{\prime \prime} \mathrm{N} 35^{\circ} 56^{\prime} 02^{\prime \prime} \mathrm{E}$ & 1144 & Sarıoğlan \\
\hline G4 & $39^{\circ} 10^{\prime} 43^{\prime \prime} \mathrm{N} 35^{\circ} 55^{\prime} 40^{\prime \prime} \mathrm{E}$ & 1127 & Sarıoğlan \\
\hline G5 & $39^{\circ} 11^{\prime} 56^{\prime \prime} \mathrm{N} 35^{\circ} 56^{\prime} 09^{\prime \prime} \mathrm{E}$ & 1157 & Sarıoğlan \\
\hline G6 & $38^{\circ} 42^{\prime} 31^{\prime \prime} \mathrm{N} 35^{\circ} 32^{\prime} 30^{\prime \prime} \mathrm{E}$ & 1108 & Talas \\
\hline G7 & $38^{\circ} 42^{\prime} 17^{\prime \prime} \mathrm{N} 35^{\circ} 32^{\prime} 19^{\prime \prime} \mathrm{E}$ & 1110 & Talas \\
\hline G8 & $38^{\circ} 42^{\prime} 16^{\prime \prime} \mathrm{N} 35^{\circ} 33^{\prime} 51^{\prime \prime} \mathrm{E}$ & 1136 & Talas \\
\hline G9 & $38^{\circ} 47^{\prime} 25^{\prime \prime} \mathrm{N} 35^{\circ} 39^{\prime} 21^{\prime \prime} \mathrm{E}$ & 1208 & Melikgazi \\
\hline G10 & $38^{\circ} 47^{\prime} 38^{\prime \prime} \mathrm{N} 35^{\circ} 41^{\prime} 51^{\prime \prime} \mathrm{E}$ & 1317 & Melikgazi \\
\hline G11 & $38^{\circ} 48^{\prime} 48^{\prime \prime} \mathrm{N} 35^{\circ} 43^{\prime} 00^{\prime \prime} \mathrm{E}$ & 1299 & Melikgazi \\
\hline G12 & $38^{\circ} 47^{\prime} 51^{\prime \prime} \mathrm{N} 35^{\circ} 42^{\prime} 12^{\prime \prime} \mathrm{E}$ & 1325 & Melikgazi \\
\hline G13 & $38^{\circ} 03^{\prime} 25^{\prime \prime} \mathrm{N} 35^{\circ} 23^{\prime} 31^{\prime \prime} \mathrm{E}$ & 1276 & Yahyalı \\
\hline G14 & $38^{\circ} 39^{\prime} 30^{\prime \prime} \mathrm{N} 35^{\circ} 28^{\prime} 51^{\prime \prime} \mathrm{E}$ & 1230 & Melikgazi \\
\hline G15 & $38^{\circ} 50^{\prime} 51^{\prime \prime} \mathrm{N} 35^{\circ} 51^{\prime} 28^{\prime \prime} \mathrm{E}$ & 1330 & Bünyan \\
\hline G16 & $38^{\circ} 50^{\prime} 33^{\prime \prime} \mathrm{N} 35^{\circ} 51^{\prime} 36^{\prime \prime} \mathrm{E}$ & 1360 & Bünyan \\
\hline G17 & $38^{\circ} 50^{\prime} 43^{\prime \prime} \mathrm{N} 35^{\circ} 51^{\prime} 14^{\prime \prime} \mathrm{E}$ & 1393 & Bünyan \\
\hline G18 & $38^{\circ} 11^{\prime} 18^{\prime \prime} \mathrm{N} 35^{\circ} 21^{\prime} 03^{\prime \prime} \mathrm{E}$ & 1089 & Yahyalı \\
\hline G19 & $38^{\circ} 10^{\prime} 58^{\prime \prime} \mathrm{N} 35^{\circ} 21^{\prime} 24^{\prime \prime} \mathrm{E}$ & 1092 & Yahyalı \\
\hline G20 & $38^{\circ} 22^{\prime} 01^{\prime \prime} \mathrm{N} 35^{\circ} 25^{\prime} 53^{\prime \prime} \mathrm{E}$ & 1150 & Develi \\
\hline G21 & $38^{\circ} 22^{\prime} 51^{\prime \prime} \mathrm{N} 35^{\circ} 27^{\prime} 21^{\prime \prime} \mathrm{E}$ & 1199 & Develi \\
\hline G22 & $38^{\circ} 23^{\prime} 11^{\prime \prime} \mathrm{N} 35^{\circ} 29^{\prime} 51^{\prime \prime} \mathrm{E}$ & 1256 & Develi \\
\hline G23 & $38^{\circ} 23^{\prime} 09^{\prime \prime} \mathrm{N} 35^{\circ} 29^{\prime} 51^{\prime \prime} \mathrm{E}$ & 1259 & Develi \\
\hline G24 & $38^{\circ} 22^{\prime} 59^{\prime \prime} \mathrm{N} 35^{\circ} 28^{\prime} 44^{\prime \prime} \mathrm{E}$ & 1221 & Develi \\
\hline
\end{tabular}




\section{Leaf and Fruit Analysis}

While determining the leaf and fruit characteristics, 20 leaves and 20 fruits randomly taken from different parts of the plant were used for each genotype. Leaf width, leaf length, petiole length, petiole thickness, fruit width and fruit length values were determined with a digital caliper (Mitutoyo Ip67) with $0.01 \mathrm{~mm}$ sensitivity. The fruit weight value was determined with a precision balance with a sensitivity of $0.01 \mathrm{~g}$, and the $\mathrm{pH}$ value was determined using a $\mathrm{pH}$ meter. Soluble solid content (SSC) of the genotypes were determined with the help of a handheld refractometer, and the color measurements $\left(L^{*}, a^{*}, b^{*}\right)$ were made with the Minolta CM-700d spectrophotometers.

\section{ISSR Marker Analysis}

DNA isolation from young leaves taken from genotypes was made according to the CTAB method (Doyle and Doyle1992). DNA Concentrations were measured by spectrophotometer (BioTek Instruments, Inc., Winooski, VT, United States) and DNA samples were prepared using TE (10 mMTris-HCl, $0.1 \mathrm{mM}$ EDTA, pH 8.0) solution. DNA samples were stored at $-20^{\circ} \mathrm{C}$. PCR components were prepared in a total volume of 15 $\mu \mathrm{l}$. PCR components consist of $2 \mu \mathrm{l}$ DNA (20 ng), 1.5 $\mathrm{ll}$ 10x PCR Buffer, $0.2 \mu \mathrm{l}$ Taq DNA polymerase (5u/ $\mu \mathrm{L}), 1 \mu \mathrm{l}$ dNTP $(2.5 \mathrm{mM}), 1.5 \mu \mathrm{MgCl}_{2}(25 \mathrm{mM}), 2 \mu \mathrm{l} 10 \mathrm{mM}$ ISSR primer, and $6.8 \mu \mathrm{l}$ of $\mathrm{H}_{2} \mathrm{O}$. The amplification reactions using Thermal cycle (Sense Quest) Lab Cycle programmed for an initial denaturation step at $94^{\circ} \mathrm{C}$ for 3 minutes, followed by 35 cycles of 1 minute at $94^{\circ} \mathrm{C}, 35$ cycles of 50 seconds at the specific annealing temperature at $53^{\circ} \mathrm{C}, 35$ cycles of 2 minutes at $72^{\circ} \mathrm{C}$ and ended with a final extension step 7 minutes at $72^{\circ} \mathrm{C}$. PCR products were electrophoresed on a $2 \%$ agarose gel prepared from 1 X TAE buffer at 110 volts for 4 hours and visualized under UV light in the gel imaging (Kodak) unit after staining with ethidium bromide.

\section{Phytochemical analysis}

Phytochemical analyzes were performed with 3 replications and 20 fruits in each replication. While the fruits are being prepared for analysis, they are first removed from the seeds with a stainless-steel knife and homogenized in a food blender. Homogenized fruit samples were placed in falcon tubes and stored at $-20^{\circ} \mathrm{C}$ until phytochemical analysis.

DPPH antioxidant activity (Free radical scavenging activity)

DPPH antioxidant activity of ECB was determined updating the method reported by Brand-Williams et al. (1995). $0.26 \mathrm{mM} \mathrm{DPPH}$ (1.1-diphenyl-2-picryl-hydrazil) solution was used in the analysis. $2900 \mu \mathrm{L}$ of ethyl alcohol and $1 \mathrm{ml}$ of DPPH solution were added to $100 \mu \mathrm{L}$ of ECB extracts. After mixing with the help of vortex, the mixture was incubated for 30 minutes in the dark. The absorbance values of the samples were read in the spectrophotometer at a wavelength of $517 \mathrm{~nm}$ and results are given as \% according to Garcia et al., 2012.

Total Flavonoids content 
The total flavonoids content of genotypes was determined by reference to a method reportedd by Chang et al. (2002). $3.3 \mathrm{ml}$ of methanol was added to $1000 \mu \mathrm{L}$ sample taken from fruit extract, and then $0.1 \mathrm{ml}$ of $10 \% \mathrm{AlCl}^{\prime} 6 \mathrm{H} 2 \mathrm{O}$ and $\mathrm{CH} 3 \mathrm{COOK}$ were added to the mixture. The measurements of the samples were made at a wavelength of $415 \mathrm{~nm}$ in a spectrophotometer, and the total flavonoids content was presented $\mathrm{mg} / 100 \mathrm{~g}$ fresh weight as catechin equivalent (CAE).

\section{Total Phenolic Compounds}

Total phenolic compounds were determined with the help of Folin-Ciocalteu's chemical. $4.1 \mathrm{~mL}$ of distilled water was added to $500 \mu \mathrm{L}$ of fresh fruit extract, and then $100 \mu \mathrm{L}$ of Folin-Ciocalteu's reagent and $2 \%$ sodium carbonate $\left(\mathrm{Na}_{2} \mathrm{CO}_{3}\right)$ were added. After the prepared solution was incubated for 2 hours in the dark, the solution was bluish in color and was analyzed at a wavelength of $760 \mathrm{~nm}$ in a spectrophotometer. Absorbance values were calculated as gallic acid and presented as $\mathrm{mg} / 100 \mathrm{~g}$ (fresh weight) (Eyduran et al., 2014).

\section{Total Anthocyanin Content}

Different $\mathrm{pH}$ methods were used to determine the total anthocyanin content of the ECB genotypes, and the samples were incubated for 2 hours in a buffer medium. Following, readings were made at 527 and $700 \mathrm{~nm}$ wavelengths. the results are given in $\mathrm{mg} / 100 \mathrm{~g}$ after converting the values to 26,900 (Gil et al., 2000).

\section{Data Analysis}

SPSS 23.0 statistical package program was used in the evaluation of morphological (including fruit and leaf characteristics) and phytochemical characteristics. Duncan's multiple comparison method was used to compare the difference between the means at the $5 \%$ significance level. Results are given as mean.

ISSR markers were scored as presence (1) or absence ( 0 ) of bands. The sizes of bands were estimated by comparison with GENESTATM 100 bp DNA ladder. To evaluate the genetic diversity among the ECB genotypes, NTSYS-pc (Version 2.11X, Rohlf 2000) software (Numerical Taxonomy and Multi-variation Analysis System) was used to constitute the similarity index and UPGMA (Unweighted Pair Group Method with Arithmetic Mean of Cluster analysis) dendrogram (Sneath and Sokal 1973).

\section{Results And Discussion}

\section{Leaf and Fruit Characteristics}

Leaf and fruit characteristics of ECB genotypes are given in Table 2 and Table 3. There were wide variations among genotypes in all parameters examined in leaves and fruits, and these differences are statistically significant. Leaf length values between $48.14 \mathrm{~mm}$ and $130.69 \mathrm{~mm}$, while leaf width values ranged from $52.25 \mathrm{~mm}$ to $135.76 \mathrm{~mm}$. For both values, the lowest results were $\mathrm{G} 1$, and the highest results were G13. In the petiole length values, the lowest value was determined in G4 with $15.94 \mathrm{~mm}$, while the 
highest value appeared in G11 with $25.09 \mathrm{~mm}$. The average value of the genotypes was $1.62 \mathrm{~mm}$ in petiole thickness, which is one of the leaf parameters examined in the study. 
Table 2

Leaf and fruit characteristics of ECB genotypes

\begin{tabular}{|c|c|c|c|c|c|c|c|}
\hline Gen. & $\begin{array}{l}\text { LL } \\
(\mathrm{mm})\end{array}$ & $\begin{array}{l}\text { LW } \\
(\mathrm{mm})\end{array}$ & $\begin{array}{l}\mathrm{PL} \\
(\mathrm{mm})\end{array}$ & $\begin{array}{l}\text { PT } \\
(\mathrm{mm})\end{array}$ & $\begin{array}{l}\mathrm{FL} \\
(\mathrm{mm})\end{array}$ & $\begin{array}{l}\text { FW } \\
(\mathrm{mm})\end{array}$ & $\begin{array}{l}\text { FWT } \\
\text { (g) }\end{array}$ \\
\hline G1 & $48.14 \mathrm{I}$ & $52.25 \mathrm{k}$ & $16.29 \mathrm{hi}$ & $1.02 \mathrm{ij}$ & $7.46 \mathrm{ij}$ & $4.64 \mathrm{~g}$ & $0.16 j$ \\
\hline G2 & 71.86 h-k & $65.47 j$ & 20.6 a-i & $1.32 \mathrm{f}-\mathrm{j}$ & $8.78 \mathrm{c}-\mathrm{g}$ & $8.54 \mathrm{a}-\mathrm{f}$ & $0.70 a b$ \\
\hline G3 & $61.15 \mathrm{jk}$ & $73.64 \mathrm{f}-\mathrm{j}$ & $20.03 c-i$ & $1.52 \mathrm{~d}-\mathrm{h}$ & $9.22 \mathrm{a}-\mathrm{d}$ & $9.40 a b$ & $0.57 \mathrm{~d}-\mathrm{h}$ \\
\hline G4 & 68.42 ijk & 71.38 hij & $15.94 \mathrm{i}$ & $1.42 \mathrm{e}-\mathrm{j}$ & $8.86 c-f$ & $9.26 a b$ & $0.58 \mathrm{c}-\mathrm{g}$ \\
\hline G5 & 82.21 e-h & $85.57 \mathrm{c}-\mathrm{g}$ & $21.19 a-h$ & $1.80 \mathrm{c}-\mathrm{f}$ & $8.22 \mathrm{e}-\mathrm{j}$ & 8.00 ef & $0.44 \mathrm{i}$ \\
\hline G6 & 71.29 h-k & $71.71 \mathrm{hij}$ & $18.46 \mathrm{f}-\mathrm{i}$ & $1.21 \mathrm{hij}$ & $7.96 f-j$ & $8.06 \mathrm{c}-\mathrm{f}$ & $0.55 \mathrm{~d}-\mathrm{h}$ \\
\hline G7 & $77.45 \mathrm{~g}-\mathrm{i}$ & $75.85 \mathrm{f}-\mathrm{j}$ & $17.98 \mathrm{ghi}$ & $1.94 \mathrm{bcd}$ & $8.44 \mathrm{c}-\mathrm{h}$ & 8.64 a-e & $0.60 \mathrm{~b}-\mathrm{e}$ \\
\hline G8 & $76.59 \mathrm{~g}-\mathrm{i}$ & $73.50 \mathrm{f}-\mathrm{j}$ & $25.27 \mathrm{a}$ & $1.27 \mathrm{~g}-\mathrm{j}$ & $8.32 \mathrm{~d}-\mathrm{I}$ & 8.32 b-f & 0.64 b-e \\
\hline G9 & $66.30 \mathrm{ijk}$ & $68.72 \mathrm{ij}$ & 24.08 a-e & $1.57 \mathrm{~d}-\mathrm{h}$ & $7.96 f-j$ & 7.88 ef & 0.53 e-i \\
\hline G10 & $82.92 \mathrm{~d}-\mathrm{h}$ & $86.44 c-f$ & $19.73 \mathrm{~d}-\mathrm{i}$ & $2.58 \mathrm{a}$ & 7.70 hij & 7.88 ef & $0.47 \mathrm{f}-\mathrm{i}$ \\
\hline G11 & $59.95 \mathrm{k}$ & $63.36 \mathrm{jk}$ & $25.09 a$ & $1.15 \mathrm{hij}$ & $7.32 \mathrm{j}$ & $7.46 \mathrm{f}$ & 0.46 ghi \\
\hline G12 & $78.72 \mathrm{f}-\mathrm{i}$ & $72.70 \mathrm{~g}-\mathrm{j}$ & 20.66 a-i & $1.75 \mathrm{c}-\mathrm{g}$ & $8.34 \mathrm{c-l}$ & 8.04 def & $0.58 \mathrm{~d}-\mathrm{g}$ \\
\hline G13 & 130.69 a & 135.76 a & $24.86 \mathrm{abc}$ & $2.34 \mathrm{ab}$ & $10.01 \mathrm{a}$ & $9.17 a b$ & $0.56 \mathrm{~d}-\mathrm{h}$ \\
\hline G14 & $89.52 \mathrm{c}-\mathrm{g}$ & $83.12 \mathrm{~d}-\mathrm{h}$ & $21.16 \mathrm{a}-\mathrm{h}$ & $1.62 \mathrm{~d}-\mathrm{h}$ & $7.84 \mathrm{~g}-\mathrm{j}$ & 7.66 ef & $0.45 \mathrm{hi}$ \\
\hline G15 & $67.96 \mathrm{ijk}$ & $68.38 \mathrm{ij}$ & 19.60 e-i & $0.95 \mathrm{j}$ & $8.88 c-f$ & $9.52 \mathrm{a}$ & 0.59 b-f \\
\hline G16 & 73.50 hij & 81.48 e-i & $22.23 \mathrm{a}-\mathrm{g}$ & 1.45 e-i & $8.78 \mathrm{c}-\mathrm{g}$ & $9.22 \mathrm{ab}$ & $0.56 \mathrm{~d}-\mathrm{h}$ \\
\hline G17 & $83.65 \mathrm{~d}-\mathrm{h}$ & $97.26 \mathrm{ab}$ & 24.59 a-d & $1.27 \mathrm{~g}-\mathrm{j}$ & $9.32 \mathrm{abc}$ & $9.54 \mathrm{a}$ & $0.57 \mathrm{~d}-\mathrm{h}$ \\
\hline G18 & $95.79 \mathrm{~cd}$ & 90.26 cde & $20.09 \mathrm{~b}-\mathrm{i}$ & $1.60 \mathrm{~d}-\mathrm{h}$ & $8.00 f_{-j}$ & $8.52 \mathrm{a}-\mathrm{f}$ & $0.70 \mathrm{abc}$ \\
\hline G19 & 94.74 cde & 91.35 cde & $25.03 \mathrm{ab}$ & $1.36 \mathrm{f}-\mathrm{j}$ & $8.10 e-j$ & 7.80 ef & $0.56 \mathrm{~d}-\mathrm{h}$ \\
\hline G20 & $91.71 \mathrm{c}-\mathrm{f}$ & $96.82 \mathrm{ab}$ & $21.10 \mathrm{a}-\mathrm{h}$ & $2.17 \mathrm{abc}$ & 8.54 c-h & $9.14 a b c$ & $0.66 \mathrm{bcd}$ \\
\hline G21 & 90.77 c-f & 90.60 cde & 23.13 a-f & 1.86 cde & 9.24 a-d & $9.42 \mathrm{ab}$ & $0.80 \mathrm{a}$ \\
\hline G22 & 73.97 hij & $76.36 \mathrm{f}-\mathrm{j}$ & $16.66 \mathrm{hi}$ & $1.60 \mathrm{~d}-\mathrm{h}$ & 9.26 a-d & 9.10 a-d & $0.61 \mathrm{~b}-\mathrm{e}$ \\
\hline G23 & $114.36 \mathrm{~b}$ & $106.32 \mathrm{~b}$ & 20.88 a-i & $2.4 \mathrm{a}$ & $9.84 a b$ & $9.44 a b$ & $0.67 \mathrm{bcd}$ \\
\hline \multicolumn{8}{|c|}{$\begin{array}{l}\text { Different lower case letters show statistically significant differences between genotypes in column ( } p \\
<0.05) \text {. }\end{array}$} \\
\hline \multicolumn{8}{|c|}{$\begin{array}{l}\text { LL: Leaf Length, LW: Leaf Width, PL: Petiole Length, PT: Petiole Thickness, FL: Fruit Length, FW: Fruit } \\
\text { Width, FWT: Fruit Wight, SSC: Soluble Solid Content }\end{array}$} \\
\hline
\end{tabular}




\begin{tabular}{|c|c|c|c|c|c|c|c|}
\hline Gen. & $\begin{array}{l}\text { LL } \\
(\mathrm{mm})\end{array}$ & $\begin{array}{l}\text { LW } \\
(\mathrm{mm})\end{array}$ & $\begin{array}{l}\mathrm{PL} \\
(\mathrm{mm})\end{array}$ & $\begin{array}{l}\text { PT } \\
(\mathrm{mm})\end{array}$ & $\begin{array}{l}\mathrm{FL} \\
(\mathrm{mm})\end{array}$ & $\begin{array}{l}\mathrm{FW} \\
(\mathrm{mm})\end{array}$ & $\begin{array}{l}\text { FWT } \\
\text { (g) }\end{array}$ \\
\hline G24 & $98.79 \mathrm{c}$ & $94.97 \mathrm{abc}$ & $16.81 \mathrm{hi}$ & $1.63 \mathrm{~d}-\mathrm{h}$ & 9.02 b-e & $9.46 \mathrm{a}$ & $0.63 \mathrm{~b}-\mathrm{e}$ \\
\hline Mean & 81.27 & 82.22 & 20.90 & 1.62 & 8.55 & 8.50 & 0.57 \\
\hline \multicolumn{8}{|c|}{$\begin{array}{l}\text { Different lower case letters show statistically significant differences between genotypes in column ( } p \\
<0.05) \text {. }\end{array}$} \\
\hline \multicolumn{8}{|c|}{$\begin{array}{l}\text { LL: Leaf Length, LW: Leaf Width, PL: Petiole Length, PT: Petiole Thickness, FL: Fruit Length, FW: Fruit } \\
\text { Width, FWT: Fruit Wight, SSC: Soluble Solid Content }\end{array}$} \\
\hline
\end{tabular}

In fruit analysis, G11 had the lowest fruit length value with $7.32 \mathrm{~mm}$. On the other hand, G13 produced the highest result compared to other genotypes with $10.01 \mathrm{~mm}$ in this parameter, as in leaf width and leaf length values. The range in fruit width values varied between $4.64 \mathrm{~mm}$ and $9.52 \mathrm{~mm}$. Fruit weight parameter is among the important fruit characteristics in ECB as in most fruit species. (Asencio et al., 2018). G1 with $0.16 \mathrm{~g}$ resulted in very low fruit weight compared to other fruit types. The highest fruit weight was detected in the $\mathrm{G} 21$ with $0.80 \mathrm{~g}$. The fruit weight values obtained from G5, G6, G9, G10, G11, G13, G14, G16, G19 yielded results below the average fruit weight values of the study. There are various morphological studies about ECB in the literature. In one of these studies, fruit length and fruit width were determined to be $11.85 \mathrm{~mm}$ and $9.60 \mathrm{~mm}$, respectively, in Viburnum opulus genotypes (Konarska and Domaciuk, 2018). In another study, it was reported that the fruit length value ranged from $1.04 \mathrm{~mm}$ to $11.85 \mathrm{~mm}$, and the fruit weight values were between $0.40 \mathrm{~g}$ and $1.80 \mathrm{~g}$ (Ozrenk et al., 2011). The study conducted with genotypes taken from the same region but different district as in the current study, fruit length was determined between $7.65 \mathrm{~mm}$ and $8.81 \mathrm{~mm}$, while fruit weight ranged from $0.30 \mathrm{~g}$ to $0.37 \mathrm{~g}$ (Polat et al., 2021).

Color characteristics of fruits affect most parameters including phytochemical structures. (Šamec et al., 2015). In the color properties evaluated in the study, the parameters ranged from 26.04(G5) to 36.71(G21) for $\mathrm{L}^{*}$ value, $22.73(\mathrm{G} 23)$ to $47.24(\mathrm{G} 13)$ for $\mathrm{a}^{*}$ value, and $8.95(\mathrm{G} 8)$ to $17.15(\mathrm{G} 13)$ for $\mathrm{b}^{*}$ value. It was determined by Taskin et al., 2019 that the $L^{*}, a^{*}, b^{*}$ values in ECB genotypes were 25.58, 35.39 and 24.60, respectively. While the average value of the genotypes in the $\mathrm{pH}$ value results was 3.08 , the average value of the genotypes in the SSC values was $10.55 \%$. SSC values were determined to be between $10.40 \%$ and $12.20 \%$ (Ozrenk et al., 2020), from $9.8 \%$ to $12.6 \%$ according to genotypes (Ersoy et al., 2017), while the $\mathrm{pH}$ value was determined as 2.9 in fresh fruits (Taskin et al.., 2021). The morphological data obtained from our study produced similar results with the studies in the literature. The reason for the partial differences can be explained by the fact that ecology and genotype differences can affect fruit characteristics. (Bostan ve İşbakan, 2020). 
Table 3

Color, $\mathrm{pH}$ and SSC values of ECB genotypes

\begin{tabular}{|c|c|c|c|c|c|}
\hline Gen. & $L^{*}$ & $a^{*}$ & $b^{*}$ & $\mathrm{pH}$ & SSC (\%) \\
\hline G1 & 29.77 b-e & $24.64 \mathrm{de}$ & $10.76 \mathrm{~d}-\mathrm{g}$ & $3.03 \mathrm{def}$ & $15.38 \mathrm{a}$ \\
\hline G2 & 29.71 b-e & $29.22 \mathrm{~cd}$ & $11.88 \mathrm{c}-\mathrm{g}$ & 3.04 def & 10.24 c-f \\
\hline G3 & $33.36 \mathrm{abc}$ & 27.93 cde & 12.86 b-e & 3.02 def & $11.40 \mathrm{bcd}$ \\
\hline G4 & 30.73 b-e & $23.78 \mathrm{de}$ & $11.72 \mathrm{c}-\mathrm{g}$ & $2.93 \mathrm{fg}$ & $10.46 c-f$ \\
\hline G5 & $26.04 \mathrm{e}$ & $46.82 \mathrm{a}$ & $16.67 \mathrm{a}$ & $3.14 \mathrm{bcd}$ & $9.28 \mathrm{efg}$ \\
\hline G6 & 29.69 b-e & $31.66 \mathrm{c}$ & $11.09 \mathrm{c}-\mathrm{g}$ & $2.96 \mathrm{efg}$ & 10.92 b-e \\
\hline G7 & $31.57 \mathrm{bcd}$ & $40.74 b$ & $15.65 \mathrm{ab}$ & $3.27 b c$ & 12.16 bc \\
\hline G8 & $28.51 \mathrm{cde}$ & $22.74 \mathrm{e}$ & $8.95 \mathrm{~g}$ & $3.29 \mathrm{~b}$ & $10.46 c-f$ \\
\hline G9 & $31.19 \mathrm{bcd}$ & $24.70 \mathrm{de}$ & $11.26 \mathrm{c}-\mathrm{g}$ & $2.91 \mathrm{fg}$ & 9.88 def \\
\hline G10 & 29.10 b-e & $23.88 \mathrm{de}$ & $9.45 \mathrm{fg}$ & $3.08 \mathrm{de}$ & $9.50 \mathrm{~d}-\mathrm{g}$ \\
\hline G11 & 29.97 b-e & $24.99 \mathrm{de}$ & $10.22 \mathrm{~d}-\mathrm{g}$ & 3.28 bc & $10.40 \mathrm{c}-\mathrm{f}$ \\
\hline G12 & 31.97 a-d & $29.60 \mathrm{~cd}$ & $12.22 \mathrm{c}-\mathrm{g}$ & $3.76 \mathrm{a}$ & $9.78 \mathrm{~d}-\mathrm{g}$ \\
\hline G13 & $27.65 \mathrm{de}$ & $47.24 \mathrm{a}$ & $17.15 \mathrm{a}$ & $3.14 \mathrm{bcd}$ & 10.96 b-e \\
\hline G14 & $31.41 \mathrm{bcd}$ & $28.88 \mathrm{~cd}$ & $9.85 \mathrm{e}-\mathrm{g}$ & $3.13 \mathrm{~cd}$ & $12.70 \mathrm{~b}$ \\
\hline G15 & 32.17 a-d & 26.30 cde & $12.45 b-f$ & $2.86 \mathrm{~g}$ & 10.80 cde \\
\hline G16 & 32.76 a-d & 26.98 cde & 12.62 b-f & $2.90 \mathrm{fg}$ & 10.52 c-f \\
\hline G17 & $33.98 a b$ & 27.56 cde & $12.61 \mathrm{~b}-\mathrm{f}$ & $2.90 \mathrm{fg}$ & $9.82 \mathrm{~d}-\mathrm{g}$ \\
\hline G18 & $33.11 \mathrm{abc}$ & $28.72 \mathrm{~cd}$ & $13.25 \mathrm{bcd}$ & $3.10 \mathrm{de}$ & 10.66 cde \\
\hline G19 & 29.59 b-e & $24.68 \mathrm{de}$ & $10.83 \mathrm{~d}-\mathrm{g}$ & $3.09 \mathrm{de}$ & 10.58 cde \\
\hline G20 & $33.58 \mathrm{abc}$ & $26.86 \mathrm{de}$ & 12.82 b-e & $2.89 \mathrm{fg}$ & $9.72 \mathrm{~d}-\mathrm{g}$ \\
\hline G21 & $36.71 \mathrm{a}$ & 27.05 cde & $14.22 \mathrm{abc}$ & $3.10 \mathrm{de}$ & $7.98 \mathrm{~g}$ \\
\hline G22 & 32.10 a-d & 27.05 cde & 12.77 b-e & $3.17 \mathrm{bcd}$ & 11.82 bc \\
\hline G23 & 28.76 b-e & $22.73 \mathrm{e}$ & $9.40 \mathrm{fg}$ & $2.90 \mathrm{fg}$ & $9.26 \mathrm{efg}$ \\
\hline G24 & $32.26 a-d$ & 26.97 cde & $12.68 b-f$ & $3.17 \mathrm{bcd}$ & $8.62 \mathrm{fg}$ \\
\hline Mean & 31.07 & 28.71 & 12.22 & 3.08 & 10.55 \\
\hline
\end{tabular}




\section{ISSR Analysis}

24 different ECB genotypes were evaluated in the study with ISSR markers. 20 different primers were used, and band formation was observed in 11 of these primers. A total of 73 scoreable bands were obtained, 44 of which were polymorphic. The base lengths of the primers ranged from $130 \mathrm{bp}$ to $1400 \mathrm{bp}$. In terms of band numbers, $\mathrm{VHV}(\mathrm{GTG})_{7}$ primer (13 bands) produced the highest number of bands, and the lowest band number was obtained from (GT) ${ }_{8}$ YA primer (3 bands). In the number of polymorphic bands, the band numbers of the primers varied between $1\left((\mathrm{AG})_{7} \mathrm{YC},(\mathrm{CA})_{6} \mathrm{AC},(\mathrm{GAA})_{6}\right)$ and $11\left(\mathrm{VHV}(\mathrm{GTG})_{7}\right.$. While the total number of bands per primer was 6.63 , the average number of bands was determined as 4.0. As the lowest polymorphism values of the primers were $20 \%$, the highest rate was obtained from (GT) $)_{8} Y A$ and (GACA) $)_{4}$ primers as $100 \%$. The mean polymorphism value of the study was $60.27 \%$. In addition, no primer producing a completely monomorphic band was found in the study (Table 4).

Molecular marker analysis studies on ECB are very limited in the literature. In a study conducted in Viburnum, it was determined that the average number of bands per primer was 12.55 and the number of polymorphic bands per primer was 6.0 with SSR markers, while the average polymorphism percentage was $66.4 \%$ (Senavaitytė, 2013). In another SSR study, 8 different SSR primers were used in ECB genotypes and a total of 97 bands which ranging from 2 bands to 10 bands were obtained. (Paulauskas, et al., 2014). In addition to SSR markers, in the ISSR study, which is a different marker used in ECB genotypes, it was determined that the base lengths of the primers varied between $440 \mathrm{bp}$ and $2650 \mathrm{bp}$, and the average polymorphism rate of the study was $55.5 \%$. In the same study, the number of bands obtained from the primers was determined in the range of 8 to 20 (Krupa- Małkiewicz et al., 2014). 
Table 4

Some data of ISSR primers that formed bands in the study

\begin{tabular}{|c|c|c|c|c|c|c|c|c|c|c|}
\hline Primer & Bp & TBN & PBN & $\begin{array}{l}\text { PR } \\
\%\end{array}$ & $p$ & $q$ & $\mathrm{Ne}$ & I & $\mathrm{He}$ & uHe \\
\hline$(\mathrm{CA})_{8} \mathrm{R}$ & $\begin{array}{l}200- \\
1100\end{array}$ & 7 & 4 & 57.14 & 0.705 & 0.295 & 1.505 & 0.428 & 0.293 & 0.299 \\
\hline$(\mathrm{GT})_{6} \mathrm{GG}$ & $\begin{array}{l}350- \\
1050\end{array}$ & 8 & 6 & 75 & 0.339 & 0.661 & 1.205 & 0.246 & 0.145 & 0.148 \\
\hline$(\mathrm{AG})_{7} \mathrm{YC}$ & $\begin{array}{l}250- \\
1000\end{array}$ & 5 & 1 & 20 & 0.853 & 0.147 & 1.127 & 0.115 & 0.078 & 0.079 \\
\hline$(\mathrm{CA})_{6} \mathrm{AC}$ & $\begin{array}{l}370- \\
950\end{array}$ & 5 & 1 & 20 & 0.859 & 0.141 & 1.141 & 0.121 & 0.083 & 0.085 \\
\hline$(\mathrm{GT})_{8} \mathrm{YA}$ & $\begin{array}{l}500- \\
800\end{array}$ & 3 & 3 & 100 & 0.525 & 0.475 & 1.542 & 0.517 & 0.338 & 0.345 \\
\hline$(A G C)_{6} G$ & $\begin{array}{l}130- \\
1000\end{array}$ & 10 & 7 & 70 & 0.552 & 0.448 & 1.569 & 0.439 & 0.307 & 0.314 \\
\hline $\mathrm{BDB}(\mathrm{CA})_{7} \mathrm{C}$ & $\begin{array}{l}200- \\
900\end{array}$ & 7 & 3 & 42.85 & 0.636 & 0.364 & 1.149 & 0.178 & 0.108 & 0.111 \\
\hline$(G A A)_{6}$ & $\begin{array}{l}350- \\
870\end{array}$ & 4 & 1 & 25 & 0.790 & 0.210 & 1.091 & 0.109 & 0.067 & 0.068 \\
\hline $\operatorname{VHV}(\mathrm{GTG})_{7}$ & $\begin{array}{l}310- \\
1400\end{array}$ & 13 & 11 & 84.61 & 0.367 & 0.633 & 1.399 & 0.362 & 0.236 & 0.241 \\
\hline$(\mathrm{TCC})_{5} \mathrm{RY}$ & $\begin{array}{l}210- \\
600\end{array}$ & 6 & 2 & 33.33 & 0.905 & 0.095 & 1.225 & 0.194 & 0.132 & 0.135 \\
\hline$(\mathrm{GACA})_{4}$ & $\begin{array}{l}250- \\
750\end{array}$ & 5 & 5 & 100 & 0.833 & 0.167 & 1.394 & 0.410 & 0.264 & 0.270 \\
\hline Mean & $\begin{array}{l}130- \\
1400\end{array}$ & 6.63 & 4.0 & 60.27 & 0.620 & 0.380 & 1.325 & 0.279 & 0.195 & 0.200 \\
\hline Total & - & 73 & 44 & - & - & - & - & - & - & - \\
\hline $\begin{array}{l}\text { Bp: Base pa } \\
\text { and p: Allel } \\
\text { heterozygo }\end{array}$ & $\begin{array}{l}\text { 3N: } \\
\text { ques }\end{array}$ & $\begin{array}{l}\text { anc } \\
\mathrm{Nu}\end{array}$ & 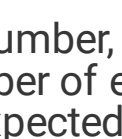 & $\begin{array}{l}\mathrm{N}: \mathrm{Pc} \\
\text { ctive }\end{array}$ & $\begin{array}{l}\text { orphi } \\
\text { les, I: }\end{array}$ & $\begin{array}{l}\text { and } r \\
\text { anno }\end{array}$ & $\begin{array}{l}\text { oer, PI } \\
\text { fform }\end{array}$ & lym & $\begin{array}{l}\text { hism I } \\
\text { He: E }\end{array}$ & cted \\
\hline
\end{tabular}

The expected and observed allelic frequency values $(p, q)$ depending on the ISSR primers ranged from $0.339\left((\mathrm{GT})_{6} \mathrm{GG}\right)$ to $0.905\left((\mathrm{TCC})_{5} \mathrm{RY}\right)$ and from $0.095\left((\mathrm{TCC})_{5} \mathrm{RY}\right)$ to $0.661\left((\mathrm{GT})_{6} \mathrm{GG}\right)$, respectively. Number of effective alleles ( $\mathrm{Ne}$ ) ranged from $1.091(\mathrm{GAA})_{6}$ to 1.569 (AGC) ${ }_{6} \mathrm{G}$ (average 1.325), Shannon's information index (I) values ranged from $0.109(\mathrm{GAA})_{6}$ to $0.517(\mathrm{GT})_{8} \mathrm{YA}$, expected heterozygosity $(\mathrm{He})$ 
values from $0.083\left((\mathrm{CA})_{6} \mathrm{AC}\right)$ to $0.338\left((\mathrm{GT})_{8} \mathrm{YA}\right)$ and unbiased expected heterozygosity (uHe) values from $0.079\left((\mathrm{AG})_{7} \mathrm{YC}\right)$ to $0.345\left((\mathrm{GT})_{8} \mathrm{YA}\right)$ (average 0.200$)$ (Table 4).

According to the UPGMA dendrogram of the genotypes, the similarity index varied between 0.77 and 0.95 , and 2 main groups were formed between the genotypes in the dendrogram. While only the G5 was in group $A$, the other 23 genotypes were in group BIn group $B$, two subgroups were formed, and in subgroup B-I the genotype $\mathrm{G} 8$ was grouped alone. According to the dendrogram, the closest genotypes to each other are $\mathrm{G} 10$ and $\mathrm{G} 24$ with a similarity index of 0.95 . In the molecular marker analysis results of the study, genotypes were randomly distributed and grouped in general, and an intense grouping of the regions from which they were taken did not emerge. In addition, all genotypes were separated from each other in the dendrogram. (Figure 3). Cophenetic correlation between ultra-metric similarity tree and similarity matrix was found to be relatively high $(r=0,73, P<0.01)$. Values of between $0.7-0.9$ indicate a well-correlation between similarity indices and dendrogram (Uzun et al., 2017). Because present value of this study showed that there was a high correlation between the similarity indices and the dendrogram, present dendrogram well represented the similarity index. It was determined wide variations among the dendrogram genotypes created according to the SSR marker analysis performed in Viburnum rufulum (Dean et al., 2015). In another study conducted in viburnum species, it was determined that ISSR and RAPD marker systems can be used to determine variations between genotypes. (Moura et al., 2013). These studies in the literature and the results of the current studies are similar, and the reason for the differences can be related to the difference in the used marker systems and genotypes.

\section{Phytochemical Content}

The result of all phytochemicals analyzes examined in ECB genotypes were found to be statistically significant. In the inhibition percentages of antioxidant activity, G2 produced a very high result with a value of $53.78 \%$ compared to other genotypes. The lowest value was determined in $\mathrm{G} 6$ with a value of $19.07 \%$. Studies have reported that antioxidant content in ECB genotypes varies considerably depending on genotypes (Kraujalyte et al., 2013; Ozdal et al., 2014). Total flavonoids content values ranged from $106.28 \mathrm{mg} \mathrm{CAE} / 100 \mathrm{~g}$ (G22) to $318.87 \mathrm{mg} \mathrm{CAE} / 100 \mathrm{~g}$ (G10). (Table 5). ECB's fruits contain different flavonoids such as hyperoside, rutin, querticin, luteolin (Yurkiv and Grytsyk, 2017). It was determined in the study conducted by Velioğlu et al., 2006 that the content of querticin is $26.1 \mathrm{mg} / 100 \mathrm{~g}$. Different studies have found that the flavonoids contained in the ECB are effective in the regulation of blood flow as well as the anti-aging effect. (Ersoy et al., 2017). 
Table 5

Pyhtochemical content of ECB genotypes.

\begin{tabular}{|c|c|c|c|c|}
\hline Gen & $\begin{array}{l}\text { Antioxidant activity } \\
\text { (\% inhibition) }\end{array}$ & $\begin{array}{l}\text { Total flavonoids } \\
\text { (mg CAE/100 g) }\end{array}$ & $\begin{array}{l}\text { Total phenolics } \\
\text { (mg GAE/100 g) }\end{array}$ & $\begin{array}{l}\text { Total Antosiyanin } \\
\text { (mg cyn-3-gluc /100 g) }\end{array}$ \\
\hline G1 & $20.21 p$ & $212.58 n$ & $674.16 \mathrm{ab}$ & $18.34 \mathrm{~d}$ \\
\hline G2 & $53.78 \mathrm{a}$ & $232.21 \mathrm{Im}$ & $514.96 \mathrm{fg}$ & 17.33 ijk \\
\hline G3 & $50.09 \mathrm{~b}$ & $259.98 \mathrm{~g}$ & $612.55 d$ & $17.48 \mathrm{f}-\mathrm{j}$ \\
\hline G4 & $31.20 \mathrm{~h}$ & $239.24 \mathrm{ij}$ & $669.65 a b$ & $18.25 \mathrm{~d}$ \\
\hline G5 & $31.81 \mathrm{~g}$ & $293.69 d$ & $667.34 \mathrm{ab}$ & $18.45 \mathrm{~d}$ \\
\hline G6 & $19.07 r$ & $242.58 \mathrm{i}$ & $675.49 a b$ & $18.13 \mathrm{de}$ \\
\hline G7 & $38.93 \mathrm{f}$ & $251.46 \mathrm{~h}$ & $647.18 \mathrm{c}$ & 17.78 efg \\
\hline G8 & $31.81 \mathrm{~g}$ & $271.09 \mathrm{e}$ & $667.91 \mathrm{ab}$ & $19.17 \mathrm{c}$ \\
\hline G9 & $31.55 \mathrm{~g}$ & $235.54 \mathrm{kl}$ & 679.57 a & $21.36 \mathrm{a}$ \\
\hline G10 & $24.87 \mathrm{k}$ & $318.87 \mathrm{a}$ & 658.91 bc & $19.00 \mathrm{c}$ \\
\hline G11 & $23.46 \mathrm{~m}$ & $251.46 \mathrm{~h}$ & $669.99 a b$ & $19.89 \mathrm{~b}$ \\
\hline G12 & $24.34 I$ & $294.43 d$ & $671.88 a b$ & $17.77 \mathrm{e}-\mathrm{h}$ \\
\hline G13 & $44.99 \mathrm{e}$ & $263.69 f$ & $579.45 \mathrm{e}$ & $16.90 \mathrm{I}$ \\
\hline G14 & $46.92 \mathrm{c}$ & $309.61 \mathrm{~b}$ & $668.09 a b$ & $19.85 b$ \\
\hline G15 & $46.05 d$ & $299.24 \mathrm{C}$ & $641.61 \mathrm{c}$ & $17.22 \mathrm{jkl}$ \\
\hline G16 & 20.30 op & 193.320 & $505.12 \mathrm{~g}$ & $17.20 \mathrm{jkl}$ \\
\hline G17 & 20.56 op & $230.72 \mathrm{~m}$ & $523.50 \mathrm{f}$ & $17.40 \mathrm{~h}-\mathrm{k}$ \\
\hline G18 & $26.19 j$ & $237.39 \mathrm{jk}$ & 657.28 bc & $18.47 \mathrm{~d}$ \\
\hline G19 & $26.36 j$ & $161.46 r$ & $641.07 \mathrm{c}$ & $18.12 \mathrm{de}$ \\
\hline G20 & 20.650 & $111.09 \mathrm{t}$ & $527.55 \mathrm{f}$ & $17.03 \mathrm{kl}$ \\
\hline G21 & $22.76 n$ & $174.06 p$ & $466.47 \mathrm{~h}$ & $16.48 \mathrm{~m}$ \\
\hline G22 & 20.56 op & $106.28 \mathrm{u}$ & $525.39 \mathrm{f}$ & $17.68 \mathrm{f}-\mathrm{i}$ \\
\hline G23 & 20.650 & $152.21 \mathrm{~s}$ & $451.07 \mathrm{~h}$ & $17.42 \mathrm{~g}-\mathrm{j}$ \\
\hline G24 & $27.24 i$ & $230.72 \mathrm{~m}$ & $668.91 \mathrm{ab}$ & 17.83 ef \\
\hline
\end{tabular}

Different lower case letters show statistically significant differences between genotypes in column ( $p$ $<0.05)$. 


\begin{tabular}{|lllll|}
\hline Gen & $\begin{array}{l}\text { Antioxidant activity } \\
(\% \text { inhibition })\end{array}$ & $\begin{array}{l}\text { Total flavonoids } \\
(\mathrm{mg} \mathrm{CAE} / 100 \mathrm{~g})\end{array}$ & $\begin{array}{l}\text { Total phenolics } \\
(\mathrm{mg} \mathrm{GAE} / \mathbf{1 0 0} \mathrm{g})\end{array}$ & $\begin{array}{l}\text { Total Antosiyanin } \\
(\mathrm{mg} \text { cyn-3-gluc } / 100 \mathrm{~g})\end{array}$ \\
\hline Mean & $\mathbf{3 0 . 1 8}$ & $\mathbf{2 3 2 , 2 1}$ & $\mathbf{6 1 1 , 0 5}$ & $\mathbf{1 8 , 1 1}$ \\
\hline
\end{tabular}

There were differences in total phenolic values depending on genotypes. The highest value was determined in G7 with $679.57 \mathrm{mg} \mathrm{GAE} / 100 \mathrm{~g}$, while the lowest value was in G23 with $451.23 \mathrm{mg} \mathrm{GAE} / 100$ g. It has been reported that the total phenolic contents of Viburnum opulus vary between 680 and 831 $\mathrm{mg} / 100 \mathrm{~g}$ depending on the cultivars (Rop et al., 2010), and $373 \mathrm{mg} / 100 \mathrm{~g}$ in another study. (Polka et al., 2019). The total anthocyanin content, which is the last phytochemical parameter examined, was found to vary from $21.36 \mathrm{mg}$ cyn-3-gluc /100 g to $16.48 \mathrm{mg}$ cyn-3-gluc /100 g in genotypes. (Table 5). The anthocyanin content in fresh fruits of ECB is in the range of $22 \mathrm{mg} / 100 \mathrm{~g}-29 \mathrm{mg} / 100 \mathrm{~g}$ (Moldovan et al., 2012) and varied between $15 \mathrm{mg} / 100 \mathrm{~g}$ and $48 \mathrm{mg} / 100 \mathrm{~g}$ depending on the genotypes (Ersoy et al., 2017). The phytochemical results of the study are generally similar to the studies in the literature. However, there are slight differences. There may be various reasons for these differences. It should be considered that the different methods and plant material used may affect the results.

In summary, the study was conducted to determine genetic diversity by using different marker techniques in 24 different genotypes collected from the districts of Kayseri region, which has a very important position in the ECB population. Wide variations in morphology and phytochemicals were observed among genotypes. It has been determined that combining it with ISSR molecular marker technique can give more reliable results in distinguishing genotypes from each other rather than using these methods alone. In addition, it is foreseen that the results of the study will provide information that will give an opinion for new research to be carried out especially on the protection and development of this species.

\section{Declarations}

Funding (No funds were used in this study.)

Conflicts of interest/Competing interests (no conflict of interest)

Availability of data and material (Available)

\section{References}

Al Ö, Ülger H, Eetekin T, Nisari M, Susar H, Ceylan D, Karatoprak GŞ (2017) The effect of gilaburu (Viburnum opulus) juice on Ehrlich ascites tumor (EAT) cell culture. Multidisciplinary Digital Publishing Institute Proceedings 1(10), 1051. 
Asencio AD, Serrano M, García-Martínez S, Pretel MT (2018) Organic acids, sugars, antioxidant activity, sensorial and other fruit characteristics of nine traditional Spanish Citrus fruits. European Food Research and Technology 244(8):1497-1508.

Bostan SZ, İşbakan H (2020) Fındıkta bitki morfolojik özellikleri ile verim ve meyve kalite özellikleri arasındaki ilişkiler. Ordu Üniversitesi Bilim ve Teknoloji Dergisi 10(1): 32-45. (in Turkish)

Brand-Williams W, Cuvelier ME, Berset CLWT (1995) Use of a free radical method to evaluate antioxidant activity. LWT-Food Science and Technology 28: 25-30

Chang CC, Yang MH, Wen HM, Chern JC (2002) Estimation of total flavonoid content in propolis by two complementary colorimetric methods. Journal of food and drug analysis, 10(3): 178-182.

Dean D, Wadl PA, Hadziabdic D, Klingeman WE, Ownley BH, Rinehart TA, Trigiano RN (2015) Analysis of genetic diversity and population structure for the native tree Viburnum rufidulum occurring in Kentucky and Tennessee. Journal of the American Society for Horticultural Science 140(6): 523-531.

Doyle JJ, Doyle JL (1990) Isolation of plant DNA from fresh tissue. Focus 12(13): 39-40.

Ersoy N, Ercisli S, Gundogdu M (2017) Evaluation of European Cranberrybush (Viburnum opulus L.) genotypes for agro-morphological, biochemical and bioactive characteristics in Turkey. Folia Horticulturae 29(2): 181-188.

Erylimaz M, Ozbiligin S, Ergene B, Yilmaz S, Altun ML, Saltan G (2013) Antimicrobial activity of Turkish Viburnum species. Bangladesh J. Bot 42: 355-360.

Eyduran SP, Ercisli S, Akin M, Beyhan Ö, Geçer MK (2014) Organic Acids, sugars, vitamin c, antioxidant capacity, and phenolic compounds in fruits of white (Morus alba L.) and black (Morus nigra L.) mulberry genotypes. Journal Applied Botany and Food Quality 88:134-138.

Garcia EJ, Oldoni TLC, Alencar SMD, Reis A, Loguercio AD, Grande RHM (2012) Antioxidant activity by DPPH assay of potential solutions to be applied on bleached teeth. Brazilian dental journal 23: 22-27.

Gil MI, Tomas-Barberan FA, Hess-Pierce B, Holcroft DM, Kader AA (2000) Antioxidant activity of pomegranate juice and its relationship with phenolic composition and processing. Journal of Agricultural and Food Chemistry 48: 4581-4589.

Gümüş SA, Avcı M (2020) Biyoçeşitlilik indisleri kullanılarak öncelikli koruma alanı seçimine bir örnek: Kargı çayı ve Karpuz çayı vadileri (Akdeniz Bölgesi-Türkiye). Coğrafya Dergisi (41): 147-164.( in Turkish)

Hosseinpour A, Haliloglu K, Tolga Cinisli K, Ozkan G, Ozturk HI, Pour-Aboughadareh A, Poczai P (2020) Application of zinc oxide nanoparticles and plant growth promoting bacteria reduces genetic impairment under salt stress in tomato (Solanum lycopersicum L.'Linda'). Agriculture 10(11): 521. 
Kajszczak D, Zakłos-Szyda M, Podsędek A (2020) Viburnum opulus L. - -a review of phytochemistry and biological effects. Nutrients 12(11): 3398.

Kalyoncu iH, Ersoy N, Elidemir AY, Karalı ME (2013) Some physico-chemical characteristics and mineral contents of gilaburu (Viburnum opulus L.) fruits in Turkey. International Journal of Agricultural and Biosystems Engineering 7(6): 424-426.

Konarska A, Domaciuk M (2018) Differences in the fruit structure and the location and content of bioactive substances in Viburnum opulus and Viburnum lantana fruits. Protoplasma 255(1): 25-41.

Krupa-Małkiewicz M, Smolik M, Barniak A, Smolik B (2014) RAPD and ISSR methods used for fingerprinting of selected accessions of Viburnum. Notulae Scientia Biologicae 6(3): 292-299.

Moldovan B, David L, Chişbora C, Cimpoiu C (2012) Degradation kinetics of anthocyanins from European cranberrybush (Viburnum opulus L.) fruit extracts. Effects of temperature, $\mathrm{pH}$ and storage solvent. Molecules 17(10): 11655-11666.

Moura M, Silva L, Caujapé-Castells J (2013) Population genetics in the conservation of the Azorean shrub Viburnum treleasei Gand. Plant Systematics and Evolution 299(10), 1809-1817.

Ozkan G, Ercisli, S, Sagbas HI, Ilhan G (2020) Diversity on fruits of wild grown European cranberrybush from coruh valley in Turkey. Erwerbs-Obstbau 62(3): 275-279.

Ozrenk K, Ilhan, G., Sagbas, H. I., Karatas, N., Ercisli, S., \& Colak, A. M. (2020). Characterization of European cranberrybush (Viburnum opulus L.) genetic resources in Turkey. Scientia Horticulturae, 273, 109611.

Ozturk HI, Dursun A, Yıldırım E, Ekinci M, Haliloğlu K, 2020. Assessment of genetic characterization of bean (Phaseolus vulgaris I.) germplasm collected from Erzincan of Turkey using microsatellite (SSR) markers. Journal of Horticultural Science Ornamental Plants 12(3):158-168.

Ozrenk K, Gündoğdu M, Keskin N, Kaya T (2011) Some physical and chemical characteristics of gilaburu (Viburnum opulus L.) fruits in Erzincan region. Iğdır Univ J Inst Sci Technol 1:9-14.

Paulauskas A, Žukauskienė J, Kupčinskienè E, Daubaras R, Česonienè L, Lazutka R, Paškevičius A (2014) Biochemical, genotoxic and microbiological properties of different Viburnum genotypes. In The vital nature sign [elektroninis išteklius]: 8th international scientific conference: abstract book. Kaunas: Vytautas Magnus university [no.8].

Polat M, Mertoğlu K, Eskimez i (2021) Physico-chemical characteristics of some gilaburu (Viburnum Opulus L.) genotypes. International Journal of Agriculture, Environment and Food Sciences 5(1): 51-55.

Polka D, Podsędek A, Koziołkiewicz M (2019). Comparison of chemical composition and antioxidant capacity of fruit, flower and bark of Viburnum opulus. Plant Foods for Human Nutrition 74(3): 436-442. 
Richard G, Pierre TS (1992) The Development of native fruit species as horticultural crops in Saskatchewan. Hort. Science 27 (8): 866, 947.

Rohlf FJ (2000) NTSYS-pc: numerical taxonomy and multivariate analysis system, version 2.1. Exeter Software, Setauket, New York.

Rop O, Reznicek V, Valsikova M, Jurikova T, Mlcek J, Kramarova D (2010) Antioxidant properties of European cranberrybush fruit (Viburnum opulus var. edule). Molecules 15(6), 4467-4477.

Šamec D, Maretić M, Lugarić I, Mešić A, Salopek-Sondi B, Duralija B (2016) Assessment of the differences in the physical, chemical and phytochemical properties of four strawberry cultivars using principal component analysis. Food chemistry 194: 828-834.

Schneider FD, Morsdorf F, Schmid B, Petchey OL, Hueni A, Schimel DS, Schaepman ME (2017) Mapping functional diversity from remotely sensed morphological and physiological forest traits. Nature communications 8(1): 1-12.

Sedat Velioglu Y, Ekici L, Poyrazoglu ES (2006) Phenolic composition of European cranberrybush (Viburnum opulus L.) berries and astringency removal of its commercial juice. International journal of food science \& technology 41(9), 1011-1015.

Senavaitytė K (2013). Paprastojo putino (Viburnum opulus L.) genetinè įvairovè (Master's thesis).

Sneath PHA. Sokal RR (1973) Numerical Taxonomy; Freeman: San Francisco, CA, USA.

Taskin O, Izli G, Izli N (2021) Physicochemical and morphological properties of European Cranberrybush powder manufactured by freeze drying. International Journal of Fruit Science 21(1): 1008-1017.

Taskin O, Izli N, Izli G (2019) Rehydration, pH, brix, titrable acidity and color variations of infrared and microwave dried European Cranberrybush. Original contributions 23(4):176-180.

Uzun A, Coskun OF, Yaman M, Pinar H, Paris K (2017) Identification of genetic similarities among walnut (Juglans regia $\mathrm{L}$ ) genotypes selected from central Anatolia region of Turkey with SRAP markers. Alatarım 16(1): 26-34.

Yıldız R, Ekici H (2019) Gilaburu (Viburnum opulus L.)'nun farmakolojik açıdan değerlendirilmesi. Veteriner Farmakoloji ve Toksikoloji Derneği Bülteni 10(1): 16-23.

Yu HQ (2020) Molecular insights into extracellular polymeric substances in activated sludge. Environmental Science \& Technology 54(13): 7742-7750.

Yurkiv K, Grytsyk A (2017) HPLC-analysis of phenolic compounds of European cranberry bush fruits (Viburnum opulus L.). The Pharma Innovation Journal 6: 526-529. 


\section{Figures}

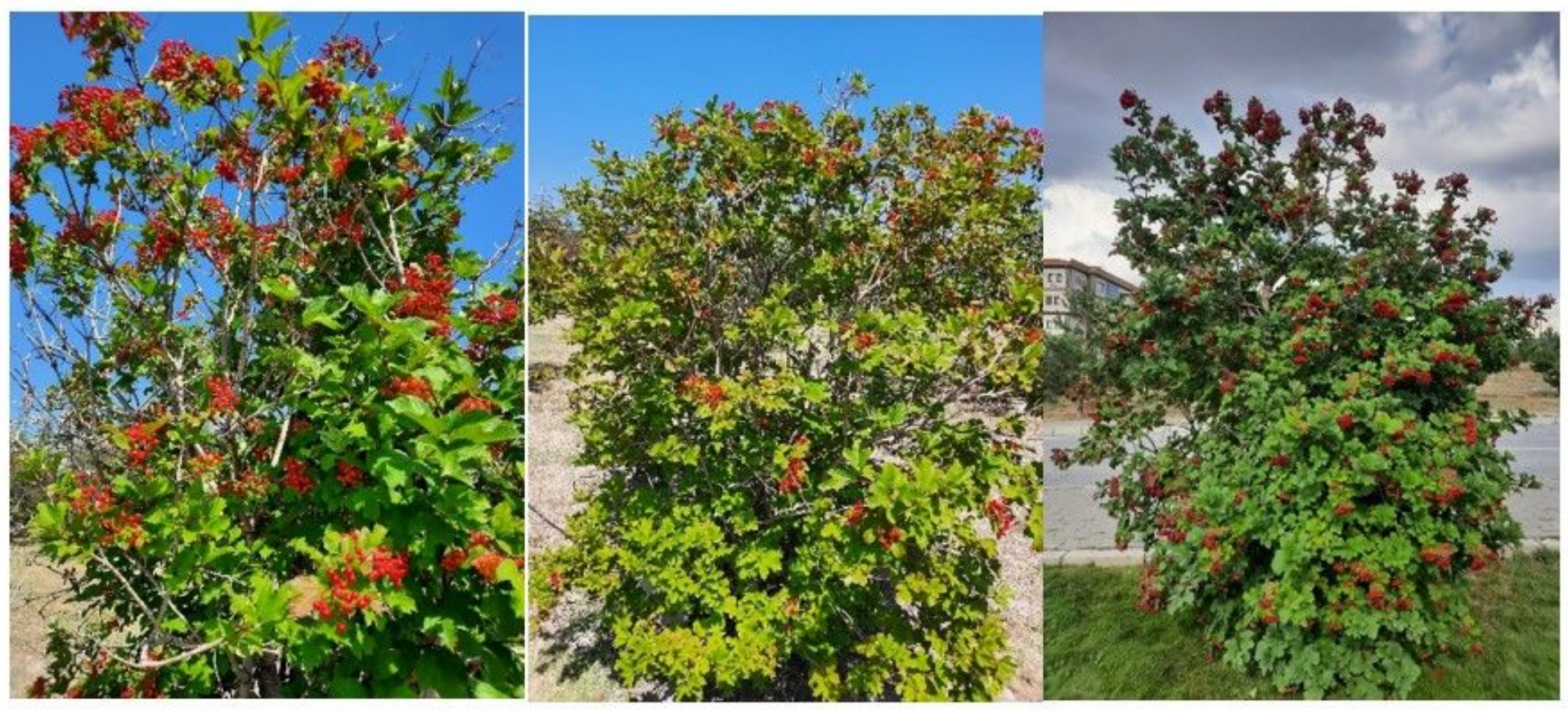

Figure 1

Some images of ECB genotypes 


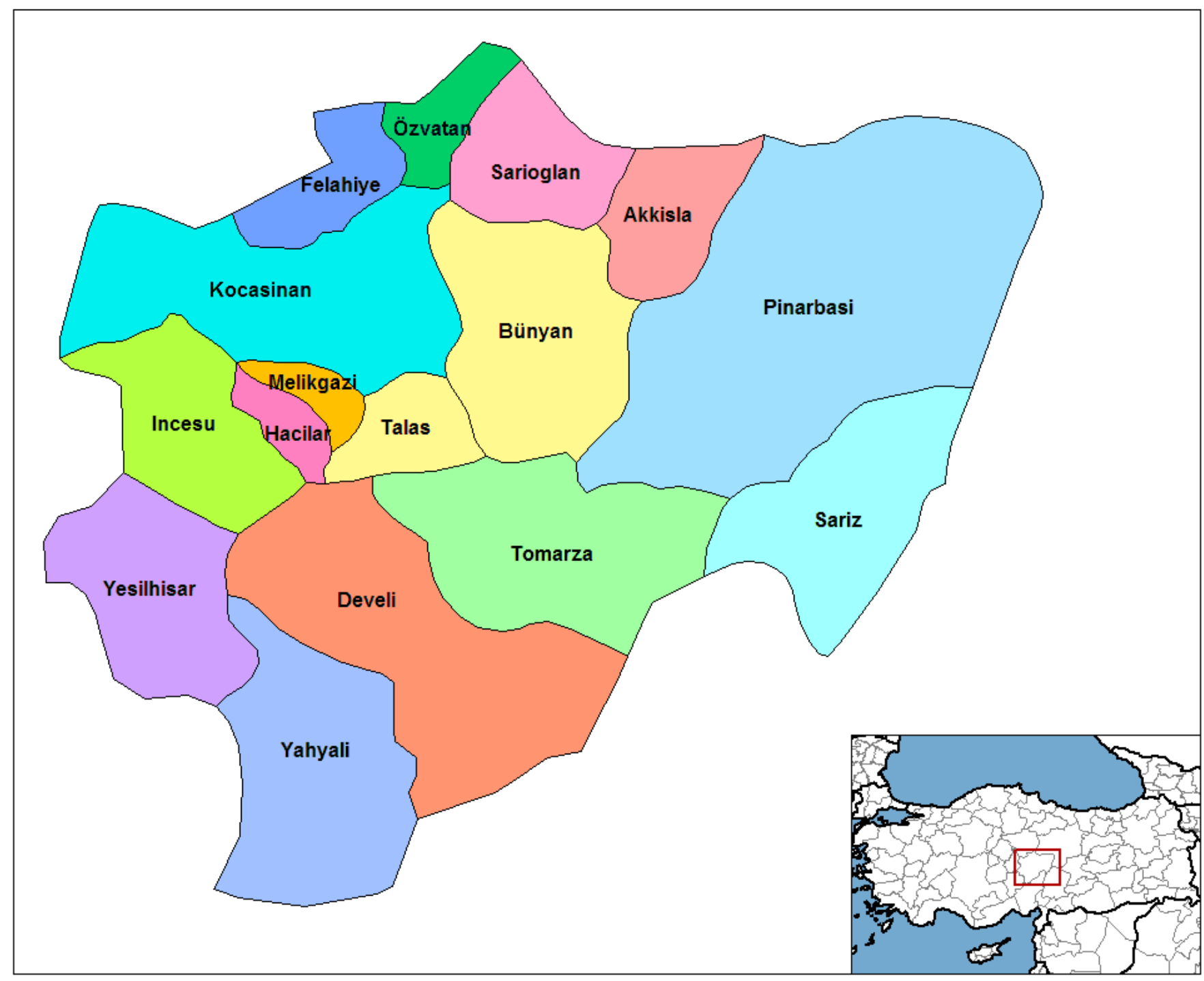

Figure 2

Map of districts where ECB genotypes were collected 


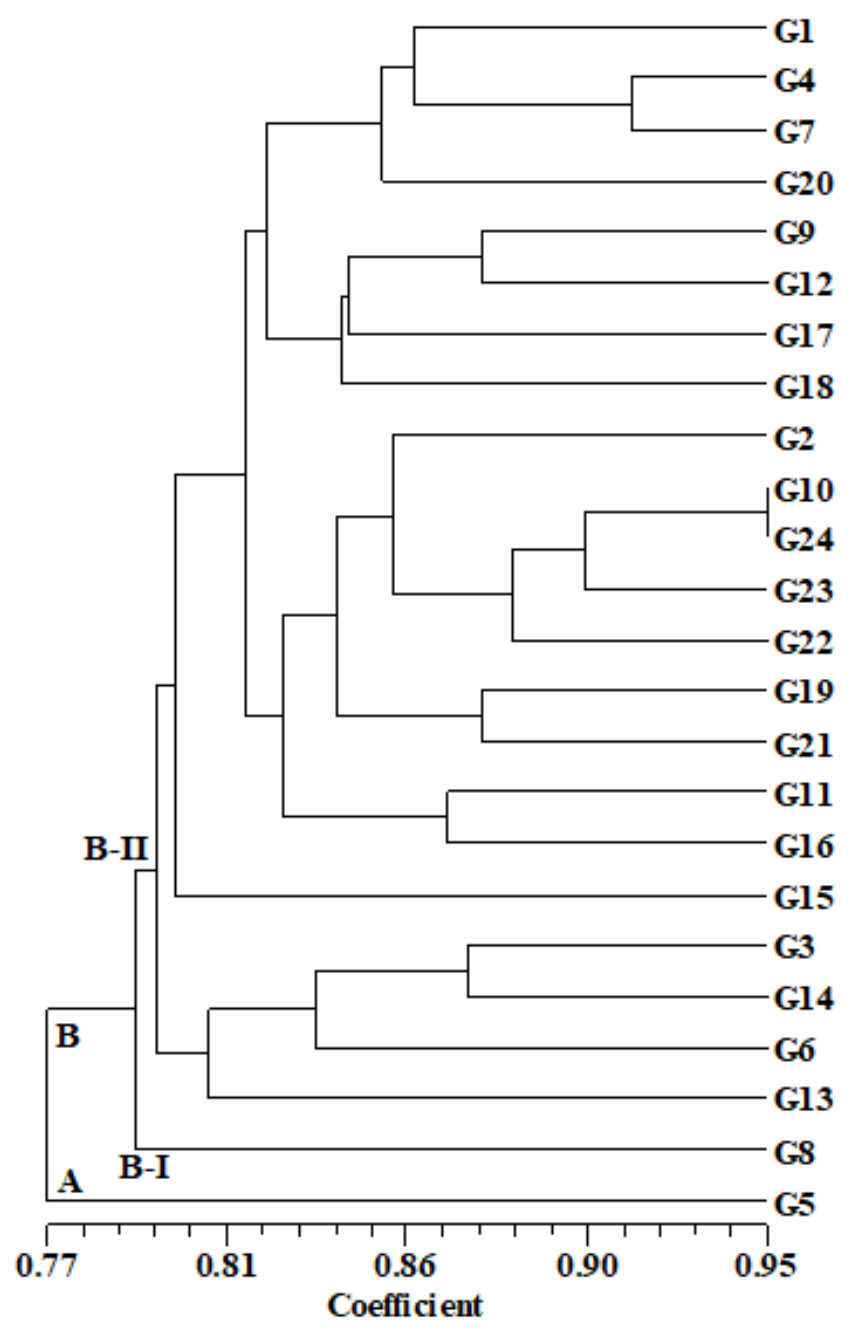

Figure 3

UPGMA dendrogram of ECB genotypes 